\title{
Analysis of Operational Performance of Crude Oil Refining and Petrochemical Jetties in Nigeria
}

\author{
Donatus. E. ONWUEGBUCHUNAM ${ }^{1}$, Moses. O. APONJOLOSUN ${ }^{1}$, Sodiq. 0. \\ BUHARI $^{2}$, Dotun 0JO ${ }^{2}$
}
${ }^{1}$ Federal University of Technology, Department of Maritime Management Technology, Nigeria
${ }^{2}$ Federal College of Fisheries and Marine Technology, Maritime Transport and Business Management Department, Nigeria
don@futo.edu.ng; ORCID ID: https://orcid.org/0000-0003-2120-9922 aponjolosunmoses@gmail.com; ORCID ID: https://orcid.org/0000-0002-3656-7370 buhari.sodiq@gmail.com; ORCID ID: https://orcid.org/0000-0003-4590-679X dot2n@yahoo.com; ORCID ID: https: //orcid.org/0000-0001-5763-0546
Corresponding Author: Moses. O. Aponjolosun

\begin{abstract}
This paper assessed the performance of jetty operations in Warri Refining and Petrochemical Company (WRPC). Primary data for the study consisted of ship turn round times, volume of cargo and number of vessels handled at the jetties for years 2004 to 2018. These variables served as key performance assessment criteria. In addition, copies of questionnaires on postulated factors affecting terminal performance were administered to a random sample of WRPC staff. Our findings showed that the jetties were being operated at less than optimum level. Trend analysis of the key performance indicators showed existence of continuous decline in operational performance of WRPC over the years covered in the study. Significant factors accounting for this performance outcome were found to include: inadequate berthing facilities, shortage of manpower supply, pipeline vandalisation, inadequate maintenance of jetty facilities and poor documentation process. The study recommended deployment of trained workforce to jetty operations, maintenance of berthing facilities, adequate funding and improved documentation of processes during jetty operations.
\end{abstract}

\section{Keywords}

Cargo Throughputs, Turn round Time, Ship Visits, Operational Performance, Petroleum Products Jetties. 


\section{Introduction}

The demand for petroleum and petroleum products in Nigeria is increasing everyday judging from the population growth at geometric rate. Increase in demand for petroleum products has necessitated the need for efficient supply chain and functional terminal/ jetty operations. Efficient and productive terminal operations are of essence given the technological advancement and globalization which has greatly influenced the pattern of production and consumption of goods [1]. After the discovery of oil in 1956 at Oloibiri, the first shipment of crude oil from Nigeria to Britain occurred in 1958. Importation of petroleum products was necessitated by growth in Nigeria's economy and increase in demand for the petroleum products. However, in order to meet the product needs of country, Shell BP built a refinery of 38,000 barrels per day production in 1965 near Port Harcourt [2]. Furthermore, rapid growth and increased economic activities led to the establishment of Warri refinery and Kaduna refinery in 1978 and 1980 respectively while the new Port Harcourt refinery was completed for operation in 1989. However, local refineries started experiencing decline in performance in the early 1990's as a result of interference by politicians [2]. The refineries were characterized by poor governance, poor turnaround time maintenance, vandalisation of pipelines supplying crude to pipelines and those conveying products from them; thus, leading to low capacity utilization [2]. The inability of the four refineries in Nigeria to meet demand for products led to frequent acute shortage of petroleum products. These challenges could be attributed to lack of innovative drive, shortage of manpower, defective operational process, re-appointment of retired staff as contract staff, buying back of refined products which were exported as refined crude oil and payment of subsidy by Nigerian government [3].

\subsection{Problem Statement}

Nigeria's four refineries have been operating below installed capacities which have made supply of petroleum products to Nigerians (population about 200 million) insufficient given high energy consumptions required by Nigeria whose population is growing rapidly. The problems of refining industry in Nigeria include corruption, theft of petroleum products, poor maintenance of pipelines and other operational challenges [4]. Warri Refining and Petrochemical Company (WRPC) which is one of the refineries in Nigeria is also saddled with these operational challenges. WRPC has a capacity of 125,000 bpd but it has never achieved full capacity utilization as production has declined steadily except in the early 1990's during which there was a brief upsurge in production [5]. The collapse of loading berth 1 and 2 at WRPC out of 4 berths in 2015 and 2016 respectively was due mainly to these operational challenges. It is anticipated that except these constraints are controlled they are likely to negatively impact performance of the refinery. Against this backdrop, this paper seeks to empirically identify significant factors affecting operational performance of Warri refinery.

\subsection{Objectives}

This study seeks to evaluate trends in performance of WRPC based on the following operational indicators: cargo throughput, vessel traffic and vessel turnround times. The study will also assess the extent in which WRPC operational performance is affected by inadequate berthing facilities, inadequate funding, shortage of manpower supply, poor maintenance of jetty facilities and slow documentation process. 


\section{Literature Review}

\subsection{Description of Warri Refinery and Petrochemical Company Jetty}

Warri refinery was established in 1978 with a refining capacity of 100,000 barrels per stream day [6]. The refinery which is operated by Warri Refining and Petrochemicals Company limited, a Nigerian National Petroleum Corporation subsidiary is situated at Ekpan, Warri, Delta state. The major products handled by WRPC are crude oil, Premium Motor Spirit (PMS), Dual Purpose Kerosene (DPK), Automobile Graded Oil (AGO), Polypropylene, Carbon Black and so on. However, WRPC jetty has Four berths but among these four berths, it is important to note that loading berth 1 (LB1) and loading berth 2 (LB2) gone out of operation (collapsed) in year 2016 and 2017 respectively [7]. Table 1 below gives a detailed description and status of the berths as at the time of carrying out this study.

\subsection{Overview of Operational Performance Measurement}

Performance indicators (or metrics) are used for measurement or assessment of performance which activity is vital for the growth and success of an organisation [8]. Key Performance Indicators (KPIs) is a set of quantifiable measures which could be used as guides for achievement of organization's strategic and operational goals [9]. These may differ from one organization to other depending on their

Table 1. Description of Characteristics of WRPC Berths

\begin{tabular}{|l|c|c|c|}
\hline \multicolumn{1}{|c|}{ Berth } & $\begin{array}{c}\text { Length } \\
\text { (M) }\end{array}$ & $\begin{array}{c}\text { Draught } \\
\text { (M) }\end{array}$ & Status \\
\hline $\begin{array}{l}\text { Cargo berth 1 } \\
\text { (CB1) }\end{array}$ & 105 & 8 & In operation \\
\hline $\begin{array}{l}\text { Cargo berth 2 } \\
\text { (CB2) }\end{array}$ & 105 & 12 & In operation \\
\hline $\begin{array}{l}\text { Loading berth 1 } \\
\text { (LB1) }\end{array}$ & 125 & 5.9 & Collapsed \\
\hline $\begin{array}{l}\text { Loading berth 2 } \\
\text { (LB2) }\end{array}$ & 125 & 12 & Collapsed \\
\hline
\end{tabular}

Source: WRPC reports (2018) priorities [9]. In evaluating the operational performance of any terminal or jetty such as oil jetty, fishing jetty, cargo jetty and so on, some key performance metrics are applied. Three performance indicators in respect to terminal or jetty operations are physical indicators, factor productivity indicators, economic/financial indicators [8]. Physical indicators address issues relating to ship turnround time, berth occupancy rate, cargo throughput and cargo dwell time. Factor productivity indicators measures variables relating to labour input and output and capital (equipment) required for stevedoring operations. Lastly the economic and financial indicators measure the income and expenditure aspect of the operation.

There are five types of performance indicators applicable to operation of oil and gas companies and these are namely: environmental performance indicators, health and safety performance indicators, social responsibility performance indicators, economic performance indicators and normalization factors [9]. Environmental performance indicators show effect of operation on the environment which includes hydrocarbon spills to the environment, greenhouse gas emissions, the extent of flared and vented gas, the level of controlled discharges to the water, biodiversity, and other environmental factors. Health and Safety performance metrics include the rate of occupational hazards, product-related health risks and workforce health. Social responsibility performance indicators include human rights, training, and development, labour practices, resettlement and land right, social investment, non-discrimination and equal right opportunity policy. Economic performance indicators include transparency of payment, capital expenditure and so on. Lastly, normalization factors include terminal, refining and pipeline throughputs, amount of cargo 
transported and production of crude oil condensates, natural gas liquids and dry gas in barrels of oil equivalent.

\section{Methodology}

The primary data for this study were obtained from copies of questionnaires administered to a random sample of WRPC staff, while the secondary data on cargo throughput, ship traffic and vessel turnround time from 2004 to 2018 were obtained from WRPC annual reports. The questionnaire was divided into two sections. Section A elicited information on demographic characteristics of respondents. Section B consisted of questions related to the effect of manpower, pipeline vandalization, documentation procedures and funding on operational performance of WRPC. A fivepoint Likert scale was used as the rating response format and this was specified as follows: strongly agree, agree, undecided, disagree and strongly disagree. One hundred copies of questionnaire were administered to staff of WRPC in nine departments. These departments are Accounts, Marine Logistics, Maintenance, Operations, Electrical, Right of Way, Human Resources, Safety and Sales. Eighty copies of questionnaires returned were completely filled. We applied test of proportions and statistical trends to analyse the data discussed.

\subsection{One Sample Proportions-Test}

This will be employed to test for significant differences if any, in the opinion of respondents regarding some questions. Test of proportion can be used to test the opinion of respondents on factors affecting performance of jetties. For example, to test the null hypothesis that operational performance of the jetties is not affected by inadequate berthing facilities, we set the null $H_{0}: P \neq 0.5$ i.e. proportion of respondents who agree, is not equal to
0.5 (or $50 \%$ of the sample), against the alternative hypothesis: $H_{1}: P=0.5$ i.e. the proportion who agreed is at least $50 \%$. The categorical data obtained from copies of questionnaires administered were recoded to make them suitable for calculating test of proportions. Thus, scores from 1 to 3 were coded as 0 to represent 'disagree' while scores 4 to 5 were coded as 1 to represent 'agree'. The Z-statistics for one sample population proportion is calculated thus:

$$
Z=\frac{\hat{P}-p}{\sqrt{\frac{p q}{n}}}
$$

$P=0,5$ is the hypothesized proportion.

$\hat{P}$ is calculated from the sample and $q=1-p$

Where $n$ is sample size from population of respondents.

Critical region: $Z<Z_{\alpha / 2}$ and $Z<-Z_{\alpha / 2}$ (For a two-tailed test)

Decision: Reject $H_{0}$ if $Z>1,96$ or $Z<-1,96$ or if $\mathrm{p}$-value $<0,05$

The sample size $\mathrm{n}$ of the population under study is 80. This was made up personnel working in WPRC.

\subsection{The Linear Trend Model}

The linear model is represented by the equation as shown:

$$
Y_{t}=\beta_{0}+\beta_{1} t+\varepsilon_{t}
$$

\section{Where}

$Y_{t}$ : Value of the dependent variable $Y$ (e.g. Volume of cargo throughput) during period $t$. $t$ : $i^{\text {th }}$ unit of time (years 2004 -2018).

$\varepsilon_{t}$ : Random movement unexplained by the trend variable during period $t$. 
The trend analysis of cargo, vessel throughputs and turnround times were conducted to assess the performance of the jetties during the observational period. In other words, we sought to find out the direction of jetty performance (upward or downward) during the study period.

\section{Data Presentation and Analyses}

\subsection{Analysis of WRPC Operational Performance}

The description of operational activities in the jetties under study for the period between 2004 and 2018 is captured in Table 2 using two indicators. Cargo volume and number of vessels handled are both indicators of output. For the period, on average about 8 billion metric tonnes of cargo and 341 vessels were handled the jetties. Based on Table 2, we note that on average vessels that called for service at the jetty spent 46 days before leaving jetty upon completion of ship operation. Ship turn round time is an indicator of service and represents in this case the quality of service received by calling vessels. It should be noted that the values of standard deviations are high in each of the variables examined.

The trend in cargo throughputs (made up loaded and discharged tonnage) in the jetties during the study period is shown in Figure 1. The slope of the graph is negative with a value of $-380.21\left(R^{2}=60.4 \%\right)$. Thus, it can be stated that in terms of output, performance of the jetties declined in the period. The same can be stated for the vessel throughput. See Figure 2. The trend in vessel traffic also declined considering the negative slope of value of $12.02\left(\mathrm{R}^{2}=\right.$ 63.6\%).

Considering ship turnround times which is a measure of performance of quality of service rendered to the vessels that called for service at the jetties, we notice a marked increment in average time spent by the vessels. A careful observation of the figures shows that in years 20042005 , there was average turnround time of 44 days, while in years 2006 to 2008 , ships spent average of 33 days. Similarly, average turnround time of vessels peaked to 44,56 and 66 days for years 2009-2014, 20152016 and 2017- 2018, respectively. Figure 3 indicates that there was positive slope (of value 1.88 and $R^{2}=64.3$ ) in the trend of ship turnround time over time. This outcome is an indication of poor performance since obviously vessels that called for service at the jetties experienced delays.

So far, the analyses of secondary data in the study showed the following: poor performance evidenced in declining level of cargo, vessel throughputs and increased turnround times. The opinion of the personnel in these jetties was sought and

Table 2. Descriptive Statistics: Operational Data of Warri Refining and Petrochemical Company (2004 - 2018)

\begin{tabular}{|l|c|c|c|c|}
\hline Variable & Mean & Std. Dev. & Min & Max \\
\hline cargo volume (000, m/t) & $8,209,240$ & 2187418 & $3,291,000$ & $10,800,000$ \\
\hline vessel traffic (count) & 341 & 67.424 & 192 & 409 \\
\hline ship turnround time (days) & 46 & 10.479 & 33 & 66 \\
\hline
\end{tabular}

Source: Authors, based on field work, (2019) 


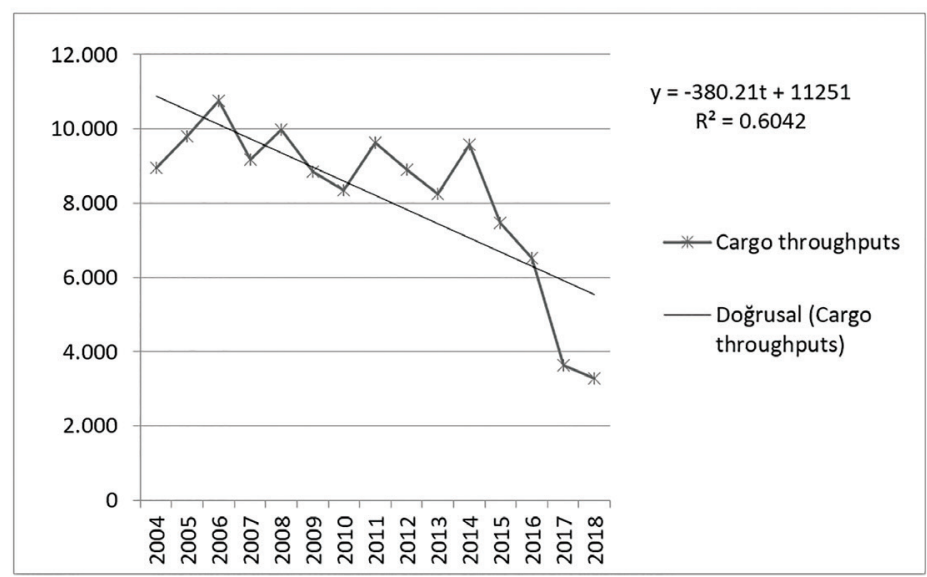

Figure 1. Trends in Cargo Throughputs Handled in Warri Refinery Company Jetties (2004 -2018)

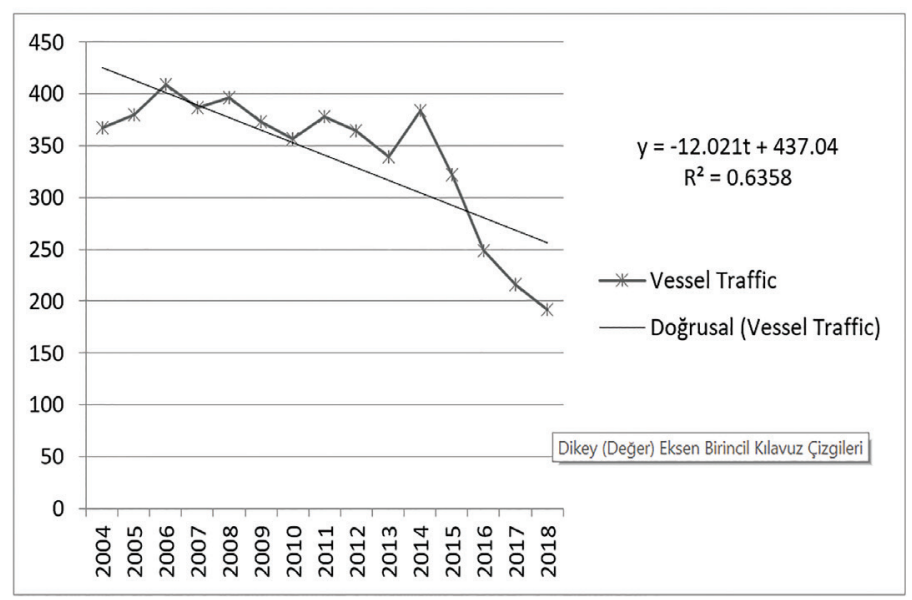

Figure 2. Trends in Vessel traffic (counts) Over the Study Period

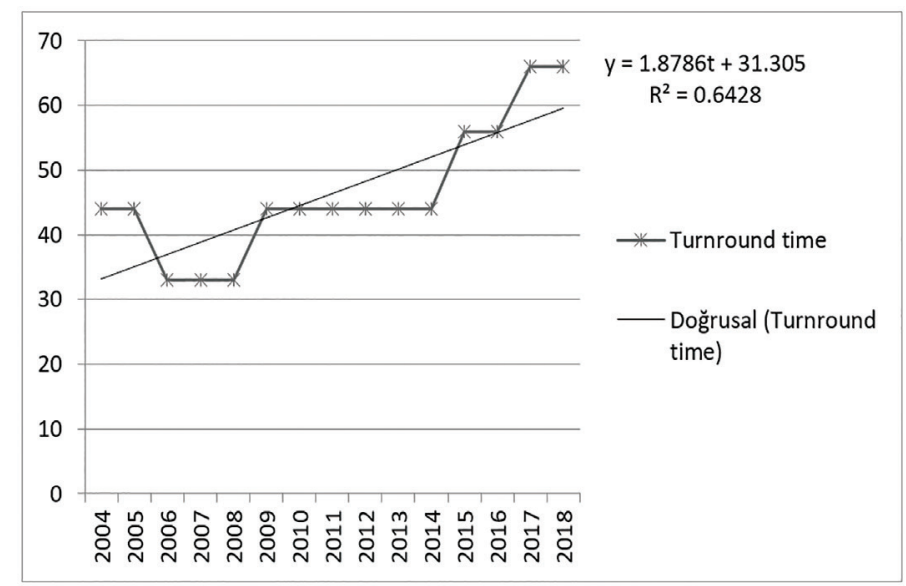

Figure 3. Trends in Turnround Times of Vessels at the Jetties 
the findings are summarized in Table 3 . The following factors affecting performance were examined: cargo handling facilities, funding, manpower resources, vandalization of pipelines feeding the jetties, jetty maintenance, and documentation procedures. From the table, the mean score of the rating response on each factor is greater than 2.5 (the mean of 5 on a Likert scale of 1 to 5 continuums). This outcome implies that these factors can be considered to collectively affect performance of jetty operation. The respondents' opinion on the level of performance at the jetty was also sought and Table 3 shows their response with a mean score of 3.75 .

To address the hypotheses implied in this study, we employed test of proportions by calculating the proportion of respondents who agreed versus those who disagreed with respect to determinants of performance and level of performance at the jetties. In Table 4, we present the results of inferential statistics and their significant values. The results show that the following significant factors affect jetty performance: inadequate berthing facilities, funding, and manpower constraints. Others are pipeline vandalization, poor maintenance of jetty facilities and poor documentation processes. These factors were statistically significant given that the calculated $\mathrm{Z}$ statistic (Z-cal.) in each case is greater than the calculated Z statistic (Z-tab.). From the output in Table 4, significant proportion of the respondents also agreed that the level performance of jetty operation was below optimum during the period.

Table 3. Descriptive Statistics: Determinants of Operational Performance in WRPC

\begin{tabular}{|l|c|c|c|c|c|}
\hline Constructs & Obs. & Mean & Std. Dev. & Min & Max \\
\hline Inadequate berthing facilities & 80 & 3.70 & 1.43 & 1 & 5 \\
\hline Inadequate funding & 80 & 3.94 & 1.45 & 1 & 5 \\
\hline Inadequate supply of manpower & 80 & 4.00 & 1.21 & 1 & 5 \\
\hline Pipeline vandalisation & 80 & 3.68 & 1.34 & 1 & 5 \\
\hline Lack of maintenance of jetty facilities & 80 & 3.69 & 1.22 & 1 & 5 \\
\hline Poor documentation & 80 & 3.53 & 1.47 & 1 & 5 \\
\hline \multicolumn{2}{|c|}{ Rating on perceived level of performance by the Respondents } & \multicolumn{2}{|c|}{5} \\
\hline WRPC has not performed optimally & 80 & 3.75 & 1.33 & 1 & 5 \\
\hline
\end{tabular}

Source: Authors

Table 4. Variable/Construct Examined

\begin{tabular}{|c|l|c|c|c|c|c|c|}
\hline Item Nos. & Factors Affecting Jetty Performance & Po & P & $\begin{array}{c}\text { Std. } \\
\text { Error. }\end{array}$ & Z-cal. & Z-tab. & $\begin{array}{c}\text { Decision: } \\
\text { Reject Ho }\end{array}$ \\
\hline i. & Inadequate berthing facilities & 0.5 & 0.70 & 0.05 & 3.58 & 1.96 & Yes \\
\hline ii. & Inadequate funding & 0.5 & 0.73 & 0.05 & 4.02 & 1.96 & Yes \\
\hline iii. & Inadequate supply of manpower & 0.5 & 0.37 & 0.05 & 5.14 & 1.96 & Yes \\
\hline iv. & Pipeline vandalization & 0.5 & 0.73 & 0.05 & 4.02 & 1.96 & Yes \\
\hline v. & Lack of maintenance of jetty facilities & 0.5 & 0.75 & 0.05 & 4.47 & 1.96 & Yes \\
\hline vi. & Poor documentation & 0.5 & 0.68 & 0.05 & 3.13 & 1.96 & Yes \\
\hline \multicolumn{2}{|c|}{ Response on Performance Level } & 0.5 & 0.73 & 0.05 & 4.02 & 2.96 & \multicolumn{4}{|c|}{ Yes } \\
\hline
\end{tabular}

Source: Authors own calculation 


\subsection{Discussion of Findings}

Within the framework of the methodology adopted for this study, we sought to assess the level of operational performancein WRPCjetties. Theindicators of output at the jetties were obtained from the volume of cargo throughputs and the number of vessels handled at the jetties during the study period. It was deduced from the trend analyses of these indicators that performance decreased. The trend in turnround time, which gives indication of quality of service received by calling vessels on the average increased-meaning that calling vessels experienced delays during the period under observation. These findings are not surprising given that the respondents stated that performance level was not optimal. Significant majority also stated that the observed sub-optimal performance was due to constraints related to the following: funding, manpower, documentation and available facilities and their maintenance.

However, it should be expected that given the consistent reduction in volume of cargo handled and vessels serviced, some facilities should have been available or idle. The possible explanation to inadequate facilities (as reported) may be that due funding, vandalization and poor facilities maintenance, the quantity and quality of available facilities were negatively affected. It is apparent from the findings that efforts should be made to improve jetty performance to improve service to vessels and increase cargo and vessel throughputs and hence improve revenue earnings. In addition, jetties provide complimentary service to ports since their operations reduce demand for service pressures evident in conventional ports.

\section{Conclusion and Recommendations}

The findings from this study showed that shortage of manpower, inadequate berthing facilities, poor documentation processes, pipeline vandalization and inadequate funding significantly affected the operational performance of WRPC. The trend analysis showed a downward trend in cargo throughput and vessel traffic while upward trend was observed in the turnround times of calling vessels. In respect to cargo throughput and vessel traffic this downward trend implied a continuous decline in operational performance of WRPC while the upward trend in respect to vessel turnround time means increase in time spent by vessels at WRPC jetty which is an indication of poor service delivery.

The study made the following recommendations as follow;

i. There is need to improve manpower resources through adequate training that will enhance their performance. It must be noted that a well-trained work force is essential for effective and efficient performance of any organization.

ii. There is need to improve berthing facilities and introduce some changes in the maintenance management policy such as the preventive and turnaround maintenance of the facilities.

iii. WRPC should be well funded and have mechanisms in place that will ensure that funds provided are spent for the purpose which they are meant for.

iv. Documentation procedures should be enhanced especially through deployment of Information, Communication and Technology (ICT) facilities.

\section{References}

[1] Madueke, U. A. (2013). Measuring and Benchmarking Efficiency and Productivity Levels of Liquid Bulk Terminal Operations Using a DEA and OEE Approach (MSc Thesis). Erasmus University Rotterdam. 
[2] Ogbuigwe, A. (2018). Refining in Nigeria: History, Challenges and Prospects. Applied Petrochemical Research, 8, 181-192. https://doi. org/10.1007/s13203-018-0211-z

[3] Igboanugo, A. C., Garba, O. M. \& Okafor, T. I. (2016). A Factorial Study of Corporate Performance of Nigerian Refineries. Nigerian Journal of Technology, 35 (1), 71-79. http:// dx.doi.org/10.4314/njt.v35i1.12

[4] Nwosu, E. (2018). Energy Mix Report. Retrieved January 15, 2020, from https://www.energymixreport. com/nigerian-refineries-challengesprivatization-option/

[5] Bureau of Public Enterprises (2018). Warri Refining Petrochemicals Company Limited. Retrieved September 10, 2019, from https:// bpe.gov.ng/warri-petrochemicalscompany

[6] Department of Petroleum Resources (2019). Petroleum Refineries and Petrochemicals. Retrieved December 05, 2019, from https://www.dpr.gov. ng/downstream/refinery/

[7] Warri Refining and Petrochemical Company (WRPC) Reports (2018). https://nnpcgroup.com/afs / Documents $/ 2018 \% 20$ Audited $\% 20$ Financial\%20Statements/WRPC\%20 2018\%20SIGNED\%20FS.pdf

[8] Sarwar, N. (2013). Time-Related Key Performance Indicators and Port Performance: A Review of Theory \& Practice (MSc Thesis). Faculty of Technology and Maritime Sciences, Vestfold University College, Norway

[9] Pedraza, J. M. (2015). What are key the KPIs for the gas processing industry. Retrieved March 15, 2020, from https://www.researchgate.net/ post/what_are_the_KPIs_for_the_-gas_ processing_industry 


\section{Appendix 1: Sample Questionnaire Used for the Study}

\begin{tabular}{|c|c|c|c|c|c|c|}
\hline \multicolumn{7}{|c|}{ SECTION A: Respondent Profile } \\
\hline \multicolumn{7}{|c|}{ Please tick the appropriate option where applicable. } \\
\hline 1. Sex & \multicolumn{6}{|l|}{ Male [ ] Female [ ] } \\
\hline $\begin{array}{l}\text { 2. Marital } \\
\text { status }\end{array}$ & \multicolumn{6}{|c|}{ Single [ ] Married [ ] Divorced [ ] Others [ ] } \\
\hline $\begin{array}{l}\text { 3. Educational } \\
\text { qualification }\end{array}$ & \multicolumn{6}{|c|}{ SSCE [ ] OND/NCE [ ] HND/BSC [ ] MSC [ ] OTHERS[ ] } \\
\hline $\begin{array}{l}4 . \\
\text { Department }\end{array}$ & \multicolumn{6}{|c|}{$\begin{array}{l}\text { Accounts [ ] Marine Logistics [ ] Maintenance [ ] Operations [ ] Electrical [ ] Right of } \\
\text { way [ ] Human Resources [ ] Health and Safety [ ] Sales [ ] }\end{array}$} \\
\hline \multicolumn{7}{|l|}{$\begin{array}{l}\text { 5. Current } \\
\text { position: }\end{array}$} \\
\hline $\begin{array}{l}\text { 6. Work } \\
\text { experience }\end{array}$ & \multicolumn{6}{|c|}{ 0-5 [ ] 6-19 [ ] 11-15 [ ] 6-20 [ ]21 and above [ ] } \\
\hline \multicolumn{7}{|c|}{$\begin{array}{l}\text { SECTION B: Please tick the appropriate option that best suits your answer in respect to the } \\
\text { operational performance of Warri Refining and Petrochemical Company (WRPC) in the table below. } \\
\begin{array}{lllll}\text { KEY: SA- Strongly Agree } & \text { A- Agree } & \text { U- Undecided } & \text { D- Disagree } & \text { SD-Strongly Disagree }\end{array}\end{array}$} \\
\hline \multicolumn{7}{|c|}{ Respondent view on WRPC operational performance } \\
\hline $\mathrm{S} / \mathrm{N}$ & STATEMENT & SA & A & $\mathrm{U}$ & $\mathrm{D}$ & SD \\
\hline 1 & $\begin{array}{l}\text { WRPC Jetty is has not performed } \\
\text { optimally. }\end{array}$ & & & & & \\
\hline 2. & $\begin{array}{l}\text { Inadequate supply of manpower } \\
\text { has negatively affected } \\
\text { operational performance }\end{array}$ & & & & & \\
\hline 3 & $\begin{array}{l}\text { Pipeline leaks as a result } \\
\text { vandalisation caused delays in } \\
\text { cargo/ship loading and discharge } \\
\text { operations WRPC }\end{array}$ & & & & & \\
\hline 4 & $\begin{array}{l}\text { Lack of maintenance of } \\
\text { jetty's facilities has affected } \\
\text { performance of WRPC }\end{array}$ & & & & & \\
\hline 5 & $\begin{array}{l}\text { Inadequate berthing facilities has } \\
\text { affected operational output of the } \\
\text { jetties }\end{array}$ & & & & & \\
\hline 6 & $\begin{array}{l}\text { Documentation procedures at the } \\
\text { jetties have affected operational } \\
\text { outputs. }\end{array}$ & & & & & \\
\hline 7 & $\begin{array}{l}\text { Operations at the jetties have } \\
\text { been hampered by insufficient } \\
\text { funding. }\end{array}$ & & & & & \\
\hline
\end{tabular}


Appendix 2: Data on WRPC's operational performance indicators (2004-2018)

\begin{tabular}{|c|c|c|c|}
\hline Year & $\begin{array}{l}\text { Cargo throughput } \\
\text { (Metric tons) }\end{array}$ & $\begin{array}{c}\text { Average Vessel } \\
\text { Turnround time } \\
\text { (days) }\end{array}$ & $\begin{array}{l}\text { Vessel Traffic } \\
\text { (counts) }\end{array}$ \\
\hline 2004 & $8,947,500$ & 44 & 367 \\
\hline 2005 & $9,810,900$ & 44 & 380 \\
\hline 2006 & $10,758,700$ & 33 & 409 \\
\hline 2007 & $9,174,000$ & 33 & 387 \\
\hline 2008 & $9,968,300$ & 33 & 396 \\
\hline 2009 & $8,843,700$ & 44 & 373 \\
\hline 2010 & $8,359,200$ & 44 & 357 \\
\hline 2011 & $9,625,400$ & 44 & 378 \\
\hline 2012 & $8,905,000$ & 44 & 364 \\
\hline 2013 & $8,240,300$ & 44 & 339 \\
\hline 2014 & $9,584,800$ & 44 & 384 \\
\hline 2015 & $7,473,800$ & 56 & 322 \\
\hline 2016 & $6,528,000$ & 56 & 249 \\
\hline 2017 & $3,628,000$ & 66 & 216 \\
\hline 2018 & $3,291,000$ & 66 & 192 \\
\hline
\end{tabular}

Source: Field study, 2019 